\title{
COURT VERDICT ANOMALY THAT DROPPED PUNISHMENT AGAINST CHILDREN UNDER 12 (TWELVE) YEARS OLD ${ }^{\Omega}$
}

\author{
Sabungan Sibarani \\ Law Faculty of Borobudur University - Jakarta \\ E-mail: ssibarani01@gmail.com
}

\begin{abstract}
The protection of children is a very serious problem and need to be considered better. That is because the child has a very important role in life of the nation in the future. Author emphasizes research how the legal effect of a District Court decision which is contrary to the Constitutional Court No. 1/PUU-VIII/2010. The author examines the problem with normative legal research methods. The research data shows that the victims are Doni Yoga (DY) who was aged 11 years old. Doni Yoga charged with the crime of theft under Article 363 paragraph (1) of the Criminal Code of the theft. The author concluded that the decisions of the cases by Pematangsiantar District Court has been at odds with the law and the Constitutional Court Decision No. 1/PUU/8/2010. However, the decision is still to be considered true and valid throughout not be appealed or an appeal that was canceled by court decision on a higher level.
\end{abstract}

Keywords: child protection, punishment, law enforcement, legal certainty

\begin{abstract}
Abstrak
Perlindungan anak merupakan masalah yang sangat serius dan perlu untuk diperhatikan dengan lebih baik. Hal tersebut dikarenakan anak memiliki peranan yang sangat penting dalam kehidupan berbangsa dan bernegara di masa yang akan datang. Permasalahannya bagaimanakah akibat hukum dari putusan Pengadilan Negeri Pematang Siantar yang bertentangan dengan Putusan MK No. 1/PUU-VIII/2010? Penulis meneliti masalah tersebut dengan metode penelitian hukum normatif. Data penelitian menunjukan bahwa yang menjadi korban adalah Doni Yoga (DY) yang masih berumur 11 tahun. Doni Yoga didakwa telah melakukan tindak pidana pencurian sebagaimana diatur dalam Pasal 363 ayat (1) KUHP tentang pencurian. Penulis berkesimpulan bahwa putusan Pengadilan Negeri Pematangsiantar yang memutus perkara Doni Yoga telah bertentangan dengan undang-undang dan Putusan Mahkamah Konstitusi No. 1/PUU/8/2010. Akan tetapi, putusan tersebut tetaplah harus dianggap benar dan valid sepanjang tidak dimintakan banding ataupun kasasi sehingga dibatalkan oleh putusan pengadilan pada tingkat yang lebih tinggi.
\end{abstract}

Kata Kunci : pemidanaan, perlindungan anak, penegakan hukum, kepastian hukum

\section{Introduction}

Unitary Republic of Indonesia is a country of law. Aristoteles stated that the reference to the country of law is a country that stands above the law for guarantee a justice to its citizens. Justice is a prerequisite to achieve happiness of citizens and as a basis of fairness that needs to be taught a sense of decency to all people to be a good citizen. ${ }^{1}$ Based on this reality, the state needs to ensure justice for all Indonesian people

$\Omega \quad$ This article is the result of research by a private fund sources (Independent) 08/JPH/XII/2015, which held based on Task Letter of Research from Dean of Law Faculty Borobudur University No. 109/SKD/FH-UB/VII/2015. and to ensure legal certainty in all respects, including the justice for children who are candidates of the nation's future.

Children protection in a community of nations, is a measurement of the nation's civilization, therefore it must be endeavored in accordance with the ability of the homeland. Activities of children protection is a legal action that resulted in the law. Related with that, a legal guarantee is needed for children protection acti-

Moh. Kusnardi and Bintan R. Saragih, 2010, Ilmu Negara, Jakarta: Gaya Media Pratama, page 131. 
vities. The legal certainty is necessary to arrange for the continuation of children protection activities and prevent abuses that bring an unintended negative consequences in the implementation of children protection. ${ }^{2}$ Based on that sentence, at least two aspects are include in this children protection activities, the first is related to the policy and government legislation of children's rights protection, and the second is policies and regulations aspects implementation. ${ }^{3}$

Indonesia in implementing the commitments of children protection has made various efforts. An Efforts to improve the welfare of children has been mandated in the Act of 1945, Act No. 4 of 1979 on Childrens Welfare, Government Regulation No.2 of 1988 regarding to the Effort of Social Welfare for Problematic Children, a ratification of the UN Convention on the Rights of the Child through Presidential Decree No. 36 of 1990, and the Compulsory 9 Year Basic Education Policy. Although there were various attempts that have been made, but we can see clearly that there are still many children who need special protection in the society.

Value of children in the community are very diverse, depend on the socio-cultural environment of society, but certainly as the time is always shifting. An understanding of the value of children is very important because it will affect the child's perception of the value of parenting parents and society towards children, as well as the policy of state/government of the children world. Country also have to understand it, thats why the Law No. 23 of 2002 on Children Protection was issued.

An efforts to protect children, as a national movement involving all segments exist, both the Government and Social Institutions Community, social organizations, religious leaders, business groups, press agencies, as well as academic institutions and the experties together in

\footnotetext{
Syaifullah Yophi Ardianto, "Perlindungan Hukum terhadap Anak Sebagai Korban Dari Tindak Pidana Perdagangan Orang Di Kota Pekanbaru", Jurnal Ilmu Hukum, Vol. 3 No. 1, 2013. Pekanbaru: Faculty of Law, Riau University.

3 I Gusti Ayu Ketut Rachmi Handayani, "Urgensi Perlindungan Anak di Indonesia (Kajian Perspektif Hukum)", Jurnal Bestuur, Vol. 2, 2013, Surakarta: Law Faculty of Sebelas Maret University, page 5 .
}

realizing Indonesian children to be a steadfast faith, educated, healthy and strong person to compete and be able to determine its future. ${ }^{4}$

United Nations (UN) in General Assembly of the United Nations which was held on November 20, 1959, has ratificated the Rights of the Child. In this declaration implied that mankind are obliged to provide the best for the children. Broadly speaking, this declaration contains ten principles on children's rights, namely the right to special protection, opportunities and facilities for children to develop in a healthy and reasonable in a free state and beneficial, has a name and nationality since their birth, social security including nutrition, housing, recreation, and health care, education, treatment, and special treatment if they are disabled, grew up in a loving atmosphere and a sense of security under the care and responsibility of their own parents get an education, and in the event of an accident or disaster, they are among the first to obtain protection and assistance, protection against all forms squandered a child, cruelty and oppression as well as action that leads into a form of discrimination.

In Indonesia as a country that adheres to the democratic system, there are various state agencies and social institutions that participa-te in law enforcement efforts. Various agencies are engaged in a variety of specific fields, including the field of children protection. ${ }^{5}$ The institutions of children protection are Komisi Perlindungan Anak Indonesia (KPAl) and the Yayasan Lembaga Bantuan Hukum Indonesia (YLBHI).

The author took the example of the of imprisonment sentence imposition for minors by the Pengadilan Negeri (PN/District Court) Pematang Siantar, as an example that will be discussed in this study. Komisi Perlindungan Anak Indonesia (KPAl) and Yayasan Lembaga Bantuan Hukum Indonesia (YLBHI) condemned the verdict

4 Rian Hidayat, "Perlindungan Anak Berbasis Komunitas Sebuah Pendekatan Dengan Mengutamakan Hak Anak", Jurnal Ilmiah, Vol. 4 No. 33, March 2014 Jakarta: Research Center and Social Welfare Development - Kementerian Sosial Republik Indonesia, page 9.

5 Elly Sudarti, "Perlindungan Hukum Terhadap Anak Dalam Proses Ajudikasi”, Jurnal Ilmu Hukum, Vol. 1 No. 5, September 2014. Jambi: Law Faculty of Jambi University, page 2. 
that has imprisoned a child who is not 12 years old yet. DY (initials) is a boy who was 11 years old who had been sentenced to 2 (two) months and 6 (six) days by a single judge of PN Pematang Siantar, Roziyanti on June 5.

The verdict is considered as contrary to Mahkamah Konstitusi (MK) decision who have changed the age limit of children who can be asked a criminally accountable initially at least 8 years old to 12 years old. The verdict was considered a misnomer, because the judges still apply the Children Court Act before it has material tested in MK that lists the age limit of children who could be convicted was 8 years old annually. ${ }^{6}$

DY who is still attending the primary school was judged to be violating to Article 363 paragraph (1) of Criminal Code and Article 4 of Law No. 3 of 1997 on Children Court. DY was found guilty of stealing a mobile phone and a laptop in March 2013. DY is released because the detention period previously had lived together with the verdict.

This is an interesting case to be analyzed and studied in depth, given the principal criminal punishment prison against DY still considered improper and even unlawful. This raises a bad precedent in order to protect the rights and interests of children who are still minors, as the future generation. Based on all of the description above, the author interested and will prepare a scientific paper entitled: Court Verdict Anomaly that Dropped Punishment against Children under 12 (Twelve) Years Old.

\section{Problems}

Based on the background described in the previous part, the authors take the formulation of the issues to be addressed in this study, namely how the legal consequences of a decision of the District Court against the verdict of the Constitutional Court No.1/PUU-VIII/2010 asso- ciated with the decision of the District Court Pematang Siantar which dropping an imprisonment against a child under twelve (12) years.

\section{Research Method}

The method in this research is the normative legal research methods, twhich is done by researching references or just the secondary data. ${ }^{7}$ That normative legal research or the literature includes studies of the general principles of law, legal systematic research, the vertical and horizontal synchronization research, comparative law, legal history. This study focused on methods of legal principles and the horizontal and vertical synchronization.

Analysis of the data used is a descriptive qualitative analysis. A qualitative approach is the procedure of the research that produced the data analysis which is the description of what was stated by the relevant research goals written or verbal and real behaviour. So by a qualitative method, a researchers were able to understand or comprehend the symptoms studied. ${ }^{8}$

\section{Discussions}

Regarding to the age limitation for child can be prosecuted the criminal responsibility, the Mahkamah Konstitusi by its ruling No. 1/ PUU-VIII/2010 Year 2010 raised the minimum age of children who can be prosecuted criminal responsibility to 12 years. This ruling once stated with the setting of a minimum limit of children who can be held accountable in the criminal Children Court Act does not have binding legal force. The rule of a minimum age limit of children who should be accountable for its criminal is stipulated in Law No. 3 of 1997 on the Children Court Before. ${ }^{9}$ Act 1 paragraph 1 Children Court Act states that the definition of a child is a person who in the case of Children has reached the age of 8 (eight) years but has not reached the

\footnotetext{
Ibid, 32.

Solehudin "Pelaksanaan Perlindungan Hukum Terhadap Pekerjaanak Yang Bekerja Di Bidang Konstruksi”, Jurnal Hukum, Jurnal Mahaiswa Fakultas Hukum, Februari 2013. Malang: Law Faculty of Brawijaya University, page 24.
}

\footnotetext{
2 No. 3, 2011, Jambi: Law Faculty of Jambi University, page 42.

Soerjono Soekanto dan Sri Mamudji, 2007, Penelitian HuGrafindo Persada, page 13-14.
} 
age of 18 (eighteen) years old and have never been married.

The Supreme Court, in practically, several times issued a decision in line with the philosophy of the Child Protection Act. For example, in one case the Supreme Court had issued a ruling stating that the maximum penalty for children is half of the maximum sentence an adult. In the case of Public Prosecutor charged the defendant is proven to have violated Article 82 of Law No. 23 The Year 2003 and sentenced to prison terms of 3 (three) years and a fine of Rp 60,000,000.00 (sixty million rupiahs). Based on the demands on Praya District Court in its decision No. 157/Pid. B/2005/PN. Pra declare the defendant found to have violated Article 82 of the Children Protection Act and sentenced to imprisonment for two (2) years and a fine of Rp 60,000,000.00 (sixty million rupiahs). Such decision was reinforced by the High Court of Mataram No. 04/Pid/2006/PT. MTR on January 25, 2006.

The punishment that is handed down by the Praya District Court in particular the imprisonment, are under threat of punishment stipulated in Article 82 of the Children Protection Act. On the basis of the public prosecutor then filed an appeal. Public Prosecutor argued that the verdict of judex facti is wrong because it does not apply these minimum penal provisions.

Cassation Public Prosecutor Request was granted by the Supreme Court of judges consisting of the Chief Justice Iskandar Kamil as a Chairman of the Council, and M. Bahaudin Qaudry, and Kamiuddin Salle as well as members of his association. But the Supreme Court judgment in this case precisely the opposite of the arguments of the Public Prosecutor. In its decision the Supreme Court had lower its penalties, especially fines of Rp. $60,000,000.00$ (sixty million rupiah) to Rp. 30.000 .000 .00 (thirty million rupiah) with the consideration that the minimum criminal penalty is half of the minimum criminal sanctions for adults, with reductions provision analogized the maximum penalty for the accu-

10 Siswadi, Imran. "Perlindungan Anak dalam Perspektif Hukum Islam dan HAM". Mawarid, Jurnal Huku Islam, Vol. XI No. 2, September-January 2011. Yogyakarta: Fa- sed child set forth in Article 26 paragraph (1) of Law No. 3 of 1997 on Children Justice.

Supreme Court's decision is not the only decision to apply or declare that the minimum criminal sanctions for the accused child is reduced by half of the threat contained in its Article. ${ }^{10}$ The next year, the Supreme Court gave a similar consideration again, namely the decision No.2824K/Pid/2006, which terminated on January 31, 2007 with 'SS' aged 14 (fourteen) years as the defendant. Acts committed by the defendant in this case is similar to the decision No. $695 \mathrm{~K} / \mathrm{Pid} / 2006$ above, namely infringement of Article 82 of Law No. 23 of 2003. In this case the District Court sentenced the accused in accordance with the minimum punishment as stipulated in Article 82 of the Child Protection Act, which is imprisonment for 3 (three) years and a fine of Rp 60,000,000.00 (sixty million rupiahs). Judex facti verdict was overturned by the Supreme Court judges with the composition similar to the composition in the previous case, except for one person at a different member to Djoko, who replaced Kaimuddin Salle as a member of the assembly.

Mentioned in Article 45 paragraph (1) of the Constitutional Court said that the Constitutional Court deciding the case based on the Constitution of 1945 in accordance with the evidence and the judge's conviction. According to the Article 10 paragraph (1) of Law No. 24 of 2003 as amended by Law No. 8 Year 2011 of the Constitutional Court, the Constitutional Court Decision has the permanent legal power directly since it is spoken and there is no remedy that can be taken. That final decision of the Constitutional Court in this Act is extends to any binding legal effect (final and binding).

In accordance with the principle of res juridicata that any judgment or decrees issued by any state officials, must be assumed to be true as long as the contents are not revoked or otherwise prove that it was not true. In this regard, the authors noticed that in fact, if viewed it deeply, then the District Court Pematang Siantar

culty of Islamic Studies, Islamic University of Indonesia, page 38 . 
can not be stated as a wrong. Constitutional Court decision on a petition for Children Court Act judicial review the minimum age for sentencing children simply states that the chapter or paragraph related not have binding legal force. What this means is that the relevant article or clause can be used by judges or not, according to the beliefs and judge's considerations. ${ }^{11}$ While at that time, there is no repair or replacement of the Children Court Act as Child Criminal Justice System Law which already exists at this time.

The deprivation of liberty is the last effort as in Article 2 paragraph I above means children are basically can not be deprived of liberty unless its forced to the interests of the settlement. Legislation above is explain and instructs that in solving the problems of children, the use of criminal law whose application is done through the children justice system be avoided as a form of protection against child considering his young age and the future is still far stretched.

Based on the description above, the legal effect of the Constitutional Court Decision No.1/ PUU-VII/2010 against the Siantara Causeway District Court's decision is legally flawed, and the verdict of the district court can not be enforced. But the court ruling the country that dropped the imprisonment of children under 12 (twelve) years in 2010 is already referred to the new Constitutional Court's decision, while the verdict on this case certainly does not meet the principles elements of the Act No. 23 of 2002 about Children Protection, including the principle of discrimination, the best interests of the child, the right to life, survival and development and respect for the child's opinion.

Guidance action, the development and protection of children, it should be the role of the community, whether through child protection agencies, religious institutions, non-governmental organizations, community organizations, social organizations, businesses, media or education institutions. ${ }^{12}$ This certainly in line with

11 MA Maskur, "Perlindungan Hukum terhadap Anak Nakal Dalam Proses Acara Pidana di Indonesia", Pandecta, Vol. 7 No. 2, Semarang: Law Faculty of Semarang State University, page. 30 . the general explanation of Children Justice Law which expressly states that the particulars of criminal sanctions against children which is determined by the difference in age of children, for children as young as 8 (eight) years to 12 (twelve) years only subject to measures, such as returned to his parents, placed on social organization, or handed over to the state, while the children who have reached 12 (twelve) years old dropped criminal. The difference of treatment is based on the growth and development of the physical, mental and social development.

In this case, the legal implications of Pematang Siantar District Court judgments, where DY should take the legal liability for errors that do not necessarily understand, and of course through this DY can do an appeal to the Supreme Court. Broadly speaking, there are aspects of the psyche, remembering childhood is a vulnerable period. At this time it usually have a personality that is not stable or not fully formed yet, or in other words, the child is still unstable and easily influenced. Surely this is the lesson for law enforcement officials, especially judges District Court Causeway Sian-tara which must comply with the Decision No. 1/PUU-VIII/2010 on February 24, 2011, the minimum age of a child can be in the court of the age of 8 to 12 years old.

\section{Conclusion}

Based on the discussion that has been presented in the previous chapter, on the part of the writer wants to express a conclusion or answer to the problems that are examined in this paper, where the legal consequences of the issuance of the Constitutional Court Decision No. 1/PUU-VII/2010 against the Pematang Siantar District Court decision is flawed. Virtually every decision issued by the Court as an institution must be true throughout the country has not been canceled or replaced by a decision of the higher institutions. This is in accordance with

12 Setya Wahyudi, "Penegakan Peradilan Pidana Anak dengan Pendekatan Hukum Progresif di Indonesia", Jurnal Dinamika Hukum, Vol. 9 No. 1, January 2009. Purwokerto: Faculty of Law, Jenderal Soedirman University, page 19. 
the legal principle of res juridicata, obviously there are those who feel aggrieved, in this case DY may take an appeal to the Supreme Court. The judge in this case obviously made a mistake of law enforcement where the Constitutional Court through Decision No. 1/PUU-VII/2010 has changed the minimum limit of punishment against children by scaling up to 12 (twelve) years old. DY which at that time was just 11 (eleven) years old should not be sentenced to prison.

Based on the conclusions above and the results of research that has been done the authors suggest that: first, there should be a law enforcement officials, as well as police, prosecutors, and judges are given a special education and training in handling under age criminal cases. The education and training should be comprehensive involving all sections of each institution to include the experts in the field of children protection and children psychology. It is necessary to do seeing how important the role of Indonesian children as the generations that will continue the life of the nation and state in Indonesia.

Second, supervising of the implementation and application of the statutory provisions concerning the provision of punishment for under age children is done. This oversight should be done either by a specific part of the institution itself, and also by the independent institutions outside law enforcement agencies that already exist.

\section{References}

Ardianto, Syaifullah Yophi. "Perlindungan Hukum Terhadap Anak Sebagai Korban Dari Tindak Pidana Perdagangan Orang di Kota Pekanbaru". Jurnal Ilmu Hukum, Vol. 3 No. 1, 2013. Pekanbaru: Faculty of Law, Riau University;

Handayani, I Gusti Ayu Ketut Rachmi. "Urgensi Perlindungan Anak di Indonesia (Kajian
Perspektif Hukum)". Jurnal Bestuur, Vol. 2, 2013, Surakarta: Law Faculty of Sebelas Maret University;

Hidayat, Rian. "Perlindungan Anak Berbasis Komunitas Sebuah Pendekatan dengan Mengutamakan Hak Anak". Jurnal Ilmiah, Vol. 4 No. 33, March 2014. Jakarta: Research Center and Social Welfare Development - Kementerian Sosial Republik Indonesia;

Kusnardi, Moh. and Bintan R. Saragih, 2010. Ilmu Negara. Jakarta: Gaya Media Pra-tama.

Maskur, MA. "Perlindungan Hukum terhadap Anak Nakal dalam Proses Acara Pidana di Indonesia”. Pandecta, Vol. 2 No. 3, 2011. Semarang: Law Faculty of Semarang State University;

Siswadi, Imran. "Perlindungan Anak dalam Perspektif Hukum Islam dan HAM". Mawarid, Jurnal Huku Islam, Vol. XI No. 2, September-January 2011. Yogyakarta: Faculty of Islamic Studies, Islamic University of Indonesia;

Soekanto, Soerjono dan Sri Mamudji. 2007, Penelitian Hukum Normatif; Suatu Tinjauan Singkat. Jakarta: RajaGrafindo Persada.

Solehudin. "Pelaksanaan Perlindungan Hukum Terhadap Pekerja Anak yang Bekerja di Bidang Konstruksi". Jurnal Hukum, Jurnal Mahaiswa Fakultas Hukum, Februari 2013. Malang: Law Faculty of Brawijaya University.

Sudarti, Elly. "Perlindungan Hukum Terhadap Anak Dalam Proses Ajudikasi”. Jurnal Ilmu Hukum, Vol. 2 No. 2, September 2014. Jambi: Law Faculty of Jambi University;

Wahyudi, Setya. "Penegakan Peradilan Pidana Anak dengan Pendekatan Hukum Progresif di Indonesia". Jurnal Dinamika Hukum, Vol. 9 No. 1, January 2009. Purwokerto: Faculty of Law, Jenderal Soedirman University;

Y, Lilik Purwastuti. "Perlindungan Hukum terhadap Anak dalam Kejahatan Terorisme". Jurnal Ilmu Hukum, Vol. 2 No. 3, 2011. Jambi: Law Faculty of Jambi University. 